\title{
How Sadness and Happiness influence Ethnic Stereotyping
}

\section{Iris Žeželj² \\ Faculty of Philosophy, Department of Psychology, University of Belgrade}

\begin{abstract}
Incidental affective states tend to influence stereotyping in counterintuitive way: experimentally induced happiness leads to more stereotyping while experimentally induced sadness leads to less stereotyping. It was therefore predicted that happy subjects would a. would make more stereotype-consistent errors in memory task; b. attribute more stereotypical features to a specific ethnic group, and c. be less sensitive to ethnic discrimination in comparison to sad subjects. In a sample of 90 high school students from Belgrade, Serbia, differently valenced affects were successfully induced using "autobiographic recollection" procedure. Experiment 1 showed that happy and sad subjects did not differ in the number of stereotype consistent errors in memory task. In experiment 2, however, happy subjects in comparison to sad subjects attributed more stereotypic traits to a non-stereotypical exemplar of a national category and expected him to behave more stereotypically in the future. Additionally, in thought listing task, happy subjects recorded more irrelevant and less story-focused thoughts in comparison to sad subjects. Finally, in Experiment $3(\mathrm{~N}=66)$ sad subjects demonstrated more sensitivity to ethnic discrimination in comparison to happy subjects. These findings are discussed in terms of the impact of emotional experience on social information-processing strategies.
\end{abstract}

Key words: Affective states, sadness, happiness, stereotyping, sensitivity to discrimination

The relation between affect and heuristic reasoning has been of considerable interest to researchers in the past few decades. Research addressed global issues such as the impact of positive and negative mood on stereotyping (Mackie \& Hamilton, 1993), as well as the impact of more

1 This research was funded by the grant from the Ministry of Education and Science of the Republic of Serbia (project number 179018). Portions of this research were presented at the International Society of Political Psychology meeting in Dublin, 2009.

2 izezelj@f.bg.ac.rs; Correspondence concerning this article should be addressed to Iris Žeželj, Department of Psychology, University of Belgrade, Čika Ljubina 18-20, 11000 Belgrade, Serbia. 
specific kinds of emotional experience within the broad categories of positive and negative affect on relying on heuristic cues (Bless, Schwartz \& Wieland, 1996; Bodenhausen, Kramer \& Susser, 1994; Bodenhausen et al., 2001).

Researchers made an important distinction between the so-called integral affect, or the emotion(s) elicited by the social group itself and the usual conditions and contexts with which the group is associated (for many stereotyped groups, this involves mostly negative feelings), and incidental affect, or emotion(s) elicited by situations unrelated to the intergroup context (Bodenhausen, 1993). For example, individuals who had been induced to feel happy usually rendered more stereotypic judgments than did those in a neutral mood (Bodenhausen, Kramer \& Susser, 1994); happy subjects were more prone to fundamental attribution error (Forgas, 1998). As for negative feelings, varieties of negative affect were found to differ in their impact on social perception: angry subjects rendered more stereotypic judgments in a social perception task than did sad subjects, and they relied more on heuristic cues in persuasion situation (Bodenhausen, Sheppard \& Kramer, 1994). Sadness was found to foster accuracy in the word-recall task, while happiness was found to induce more false memories (Storbeck \& Clore, 2005); sadness led to more reliable eyewitness testimonies and less susceptibility to misinformation (Forgas, Vargas \& Lagham, 2005); sad subjects were found to produce better arguments and more effective interpersonal persuasive messages in comparison to happy subjects (Forgas, 2007). Recent studies suggest that specific emotions, rather than emotional valence, drive depth-ofprocessing effects (see Lerner \& Tiedens, 2006).

Although there are exceptions (e.g. Ric, 2004), it appears that individuals in happy moods often rely on heuristics and generic knowledge structures when making judgments, while sad mood tends to induce more information elaboration and more detailed processing.

If mood can have pervasive effects on social information processing, it may affect the propensity to stereotype members of a social group, even when they arise for reasons having nothing to do with the group or its members.

\section{Hypothesis}

Running under the assumption that affective states can foster or discourage heuristic reasoning, it was expected that induced happiness would increase, and induced sadness would decrease stereotype-based inferences. More precisely, it was hypothesized that:

- Happy subjects will make more stereotype congruent errors in memory task than sad subjects.

- In comparison to sad subjects, happy subjects will attribute more stereotypic traits to a fictional non-stereotypically portrayed out-group member. 
- In comparison to sad subjects, happy subjects will perceive more probable that fictional out-group member will take part in negatively viewed actions in the future.

- Happy subjects will more often report that they relied on nationality instead on personal features in the reasoning process.

- In thought listing task, happy subjects will report more irrelevant and less story-focused thoughts.

- Happy subjects will be less sensitive to discriminatory behaviour in comparison to sad subjects.

\section{Experiment one}

This experiment was designed to explore impact of induced affect on stereotype congruent recollection. After presenting participants in happy or sad mood with a list of names (Albanian, Serbian and Other), participants were asked whether each name on the list belonged to the category "baker" or "lawyer" on the list that was previously read to them. First and last names typical of certain nationality were used as stimuli because they are simple yet effective communicators of social categories. I modified the procedure created by Park and Banaji (2000), in which they provided the respondents with the list of 50 European American and African American names, and asked them to assess for each name if he/she was a politician or criminal. The procedure used in the current study was designed to demonstrate how relying on stereotypical knowledge about social groups can induce memory errors - false identification of category exemplars.

\section{Method}

\section{Participants}

A total of 89 high school students from three high schools in Belgrade, Serbia participated in this experiment (all participants were older than 18, their average age was 18;8). Informed consent from participants was obtained and they were specifically told that they could refrain from participation at any given point of time. School principals and teachers were also informed about the research and its purpose. Participants received compensation in school material (educational DVDs).

\section{Design}

The design was a 2 (mood: happy vs. sad) $\times 2$ (target nationality: Albanian vs. Serbian) $\times 2$ (task: occupation baker vs. occupation lawyer) mixed design with the latter two factors manipulated within participants. 


\section{Material}

In creating a name list, I started with a large database of names (mostly from Internet sources -e.g. local municipalities birth registers), which was narrowed down to 50 Serbian and 50 Albanian names. Next, 48 psychology students were asked to rate the national typicality of each name on a 7-point scale. They participated in exchange for partial credit in an introductory psychology course. The stimuli list consisted of 12 Albanian and 12 Serbian names, rated as the most typical (Malb=5.7 $(S D=1.3)$; Mser $=5.82(S D=1.6))$. Eight "buffer names", representing other national groups (Hungarians and Bulgarians), were also included.

As for choice of occupational categories, their national typicality was pretested. The same 48 students were asked to write down the most typical occupations for Serbians and Albanians (listed in Table 1). For each profession, typicality index was calculated as a proportion of respondents who listed it and the total number of respondents. Finally, I opted for a baker as a typical occupation for Albanians, and a lawyer as a typical occupation for Serbians, as some professions were highly frequent on both lists (i.e. a merchant and farmer).

Table 1: Typical occupations by nationality

\begin{tabular}{|c|c|c|}
\hline \multirow{4}{*}{ Serbian } & Occupation & Typicality index \\
\cline { 2 - 3 } & Farmer & .48 \\
\cline { 2 - 3 } & Merchant & .46 \\
\cline { 2 - 3 } & Lawyer & .41 \\
\cline { 2 - 3 } & Teacher & .31 \\
\cline { 2 - 3 } & Medical doctor & .29 \\
\hline \multirow{5}{*}{ Albanian } & Baker & .58 \\
\cline { 2 - 3 } & Ice cream vendor & .56 \\
\cline { 2 - 3 } & Merchant & .36 \\
\cline { 2 - 3 } & Farmer & .29 \\
\cline { 2 - 3 } & Labourer (physical worker) & \\
\cline { 2 - 3 } & &
\end{tabular}

Final list consisted of 32 names (12 Serbian, 12 Albanian and 8 buffer names), which were randomly assigned to one occupation (either baker or lawyer). The order of presentation was randomized across subjects.

\section{Procedure}

Upon arrival, each participant was greeted by an experimenter and informed about participating in two different experiments, an "autobiographic memory" study and, subsequently, a "name recognition" study.

In order to experimentally induce different moods, the autobiographic recollection technique was implemented. This technique is widely used 
research of Bodenhausen and his associates (Bodenhausen, Kramer \& Susser, 1994; Bodenhausen, Sheppard \& Kramer 1994; Bodenhausen, Gabriel \& Lineberger, 2000), as well as in other author's work (e.g. Schwarz et al. 1985). Its basic assumption is that recollection of personal memories with specific emotional hue will provoke that specific emotion.

Participants were randomly assigned to either a positive or a negative mood condition. They were provided with a blank piece of paper and asked to write down in detail five happy or sad events from their personal experience, with the accent on their feelings at the time. They had 10 minutes for this task. After that, they indicated their current mood on an 11-point scale, ranging from extreme sadness to extreme happiness. This scale was embedded in a list of six buffer-scales.

After experimentally inducing the specific mood, the name list was read aloud to participants: the same printed list was also provided to each participant. In that way they could memorize it using both audio and visual cues. They were then asked to fill in some irrelevant personal data, a task that served as a buffer between two stages of the memory task.

In the next phase, the respondents were presented with the same name list with randomized stimuli, and they were asked to indicate the occupation for every given name.

At the end, participants were individually debriefed and thanked.

\section{Results}

\section{Mood Manipulation Check}

As expected, participants in the condition recalling happy autobiographic events (positive mood induction) reported experiencing a more positive mood $($ Mhap $=8.97(S D=1.37))$ than those in the condition recalling sad autobiographic events (negative mood induction), $(\mathrm{Msad}=3.63, S D=1.40)$; $F(1,88)=221.08, p<.0001)$.

\section{Affect impact on stereotypic recollection}

Proportion of stereotype congruent error served as a dependent variable. It was calculated as a ratio between the number of stereotype congruent errors (i.e. Albanian baker or Serbian lawyer) and the total number of errors. If that proportion took value of more than .5 , it was concluded that the participant made more stereotypic errors than could be expected by chance.

The proportion indicated that stereotypic recollection was present in both mood conditions - it significantly differed from .5 (Mhap $=.59,(t(88)=11.87 ; p$ $<.0001) ; \mathrm{Msad}=.61,(t(88)=12.17 ; p<.0001)$, and analysis of variance revealed no statistically significant difference between them. 


\section{Experiment two}

The aim of experiment two was to investigate the impact of incidental affective state on tendency to attribute stereotypic traits to a fictional atypical category exemplar. A moderately atypical description of a fictional Albanian was chosen and read to participants. They were asked to assess his character on a list of traits, and to judge the probability for him to take part in different activities in the future. Our assumption was that happy subjects will attribute more negative stereotypical traits to the target person in comparison to sad subjects, and that happy subjects will expect him to behave more stereotypically congruent in the future than sad subjects.

\section{Method}

\section{Participants}

The same 89 high school students as in the first experiment took part in the second experiment, which was conducted one week later. One questionnaire was omitted due to incomplete data.

\section{Material and procedure}

Re-evoking the emotions. Participants were asked to read their autobiographic descriptions again, and instructed to add something if they felt it was necessary. They had 5 minutes for this task.

Presentation of exemplar. Participants listened to a tape-recorded description about a specific person extracted from a radio program. This person was described as an Albanian, a member of the ethnic group towards which many Serbians hold strong negative stereotypes (Popadić \& Biro, 2002). The vignette was designed to fulfil several purposes. Following the suggestions from Bless, Schwarz, Bodenhausen and Thiel (2001), the target person was described rather favourably, the description included elements that indicated that the target was well integrated into the Albanian culture. At the same time, the description also included elements suggesting that the target was somewhat exceptional and not too typical for the group. In this vignette, there was a portrait of an 18 year-old boy called Azem, who lives in a multigenerational family household, and who is an average student of Gymnasium in Skoplje. He was described as an amiable person who enjoys his everyday activities - playing soccer with friends, going out at night and surfing the Internet. It was also mentioned that he is a persistent person who invests a lot of effort in things he cares deeply about. This portrait was chosen as moderately typical among three descriptions in a pretest (Table 2). 
Table 2: Average scores and frequency ranks on typicality for vignettes in a pretest

\begin{tabular}{|c|c|c|c|}
\hline & Description 1 & Description 2 & Description 3 \\
\hline $\begin{array}{c}\text { Average score on typicality } \\
\text { (scale -3 to 3) }\end{array}$ & 1.488 & -0.139 & -0.581 \\
\hline Rank 1 (frequency) & 20 & 5 & 18 \\
\hline Rank 2 (frequency) & 12 & 29 & 2 \\
\hline Rank 3 (frequency) & 11 & 9 & 23 \\
\hline
\end{tabular}

Note: higher score/rank indicates less typical description

Buffer-task. This task was introduced in the procedure in order to make information from the description less accessible in the memory, assuming that the respondents would rely more on their general knowledge. The participants were asked to complete a motor reproduction (hand drawing) task from the Bender Gestalt test. They had 5 minutes for this task.

Assessment of the target and thought listing. Three questionnaires were administered: a. the questionnaire for stereotypic trait attribution (Popadic \& Biro, 2002) consisting of 15 bipolar attributes ranging from -3 to 3 ; b. the questionnaire for judging the probabilities of life events, constructed for this research (it consists of 10 future events, and respondents are asked to judge the probability of each on the scale from one (highly improbable) to five (highly probable)); c. retrospective thought-listing task (respondents were asked to write down all the thoughts they had as they processed the story); they were also asked to report whether they based their decisions about the target person on his personal characteristic or his nationality.

\section{Results}

\section{Mood Manipulation Check}

Manipulation check revealed significant difference in affective state between happy and sad groups $(F(1,87)=189.2, p<.0001)$.

\section{Relying on stereotypes in target assessment}

In line with our assumptions, the sad group made more positive (less stereotypical) assessments of the target on all presented traits in comparison to the happy group. Assessments on overall score and on five out of fifteen scales reached significance (Table 3). The same pattern of results was registered in future events probability assessment: the sad group expected the target person to behave more positively (less stereotypical) in the future (Table 4). 
Table 3: Attribution of stereotypic traits by affective state

\begin{tabular}{|l|c|c|c|}
\hline & \multicolumn{2}{|c|}{ Affective state } & \\
\hline & Happy & Sad & F statistic \\
\hline Lazy - Hard working & 0.41 & 1.20 & 2.385 \\
\hline Coward - Brave & -1.03 & -0.10 & $3.873^{*}$ \\
\hline Stupid - Intelligent & -0.33 & 0.70 & $4.129^{\star}$ \\
\hline Cold - Sensitive & 0.66 & 1.17 & 1.064 \\
\hline Insincere - Sincere & 0.03 & 1.13 & $5.647^{*}$ \\
\hline Dishonest - Honest & -0.27 & 1.17 & $9.026^{\star *}$ \\
\hline Ill-mannered - Well-mannered & 0.13 & 0.86 & 2.116 \\
\hline Dirty - Clean & -0.47 & 0.43 & 2.744 \\
\hline Rude - Polite & -0.07 & 0.63 & 2.282 \\
\hline Inhospitable - Hospitable & -0.20 & 0.10 & .396 \\
\hline Violent - Peaceful & 0.10 & 0.60 & 1.046 \\
\hline Selfish - Altruistic & -0.13 & 0.47 & 1.431 \\
\hline Primitive - Civilized & 0.17 & 1.23 & $4.031^{\star}$ \\
\hline $\begin{array}{l}\text { Doesn't like other nations - Likes other } \\
\text { nations }\end{array}$ & -0.27 & 0.63 & 2.406 \\
\hline Not proud - Proud & 0.33 & 1.00 & 1.871 \\
\hline Total score & -0.63 & 0.75 & $11.987^{\star *}$ \\
\hline
\end{tabular}

Note: ${ }^{\star}$ marks significant difference at .05 level; ${ }^{* \star}$ marks significant difference at .01 level

Table 4: Future activities probability assessment

\begin{tabular}{|l|c|c|c|}
\hline & \multicolumn{2}{|c|}{ Affective state } & \\
\hline & Happy & Sad & F statistic \\
\hline Donate blood & 2.90 & 3.10 & .373 \\
\hline $\begin{array}{l}\text { Attend slava (Serbian religious festivity) at his } \\
\text { friend's house }\end{array}$ & 2.73 & 3.07 & .734 \\
\hline Enrol in college & 2.28 & 2.70 & 1.349 \\
\hline Help a stranger suffocating in restaurant & 3.38 & 3.67 & .622 \\
\hline Get involved in illegal business & 2.93 & 2.33 & $3.683^{*}$ \\
\hline $\begin{array}{l}\text { Support his daughter in bringing } \\
\text { up an illegitimate child }\end{array}$ & 2.47 & 2.83 & 1.223 \\
\hline $\begin{array}{l}\text { Donate money for a Serbian humanitarian } \\
\text { organization }\end{array}$ & 2.27 & 3.13 & $5.476^{*}$ \\
\hline Cheat on his wife & 3.30 & 2.47 & $4.450^{*}$ \\
\hline Attend Guča festival (Serbian folk festival) & 2.33 & 2.67 & .747 \\
\hline
\end{tabular}

Note: ${ }^{\star}$ marks significant difference at .05 level; ${ }^{* *}$ marks significant difference at .01 level 
When asked an open question regarding their decision making, the happy group more frequently mentioned target's nationality as a base for decisions, while the sad group mentioned target's personal characteristics more often $\left(X^{2}=10,275(1,87), p<.0001\right)$ (Table 5). In the thought-listing task, more irrelevant (not story-based) thoughts were registered in the happy group in comparison to the sad group $\left(X^{2}=6.474(1,87), p<.05\right)$ (Table 6).

Table 5: Arguments in judging the probability of future events

\begin{tabular}{|c|c|c|c|}
\hline & \multicolumn{2}{|c|}{$\begin{array}{c}\text { What were your arguments when judging the probability of } \\
\text { target's future actions? }\end{array}$} & \\
\hline & Personal characteristic & Nationality & Total \\
\hline Happy & $19(42 \%)$ & $26(58 \%)$ & 45 \\
\hline Sad & $33(77 \%)$ & $10(23 \%)$ & 43 \\
\hline
\end{tabular}

Table 6: Thought relevance in thought-listing task

\begin{tabular}{|c|c|c|c|}
\hline & \multicolumn{2}{|c|}{ Thought relevance } & \\
\hline & Focused on story (relevant) & Other thoughts (irrelevant) & Total \\
\hline Happy & $22(48 \%)$ & $23(52 \%)$ & 45 \\
\hline Sad & $34(80 \%)$ & $9(20 \%)$ & 43 \\
\hline
\end{tabular}

\section{Experiment three}

The third study attempted to test the impact of sadness and happiness on a different type of judgment: namely, on identifying discriminatory behaviours towards the out-group. Perceived discrimination is stated to be a precondition for individual actions against inequality and support for policies addressing the inequalities on a broader level (Kluegel \& Bobo, 2001). It is therefore important to test if people's sensitivity to discriminatory verbal behaviours (i.e. comments, labelling and racist jokes) is biased by their incidental affective state. Following the previous line of argumentation, it was expected that sad participants would demonstrate heightened sensitivity towards out-group discrimination in comparison to happy ones.

\section{Method}

\section{Participants}

Sixty nine third-year psychology students took part in exchange for course credits. They were randomly assigned to happy/sad experimental condition.

\section{Material and procedure}

Subjects were informed about participating in two different experiments, an "autobiographic memory" study, followed by a study on "interpreting Internet news". 
Mood induction procedure was identical to the one described in the first experiment.

In the second phase of experiment, I presented participants with 633word long Internet news describing the re-allocation of a Roma settlement in Novi Beograd, Serbia. The news contained a brief description of the event, as well as reactions from a non-governmental organization and the Belgrade mayor. The former expressed concern that there were human right violations in the process, whilst the latter insisted that Roma people were offered better living conditions, job and schooling opportunities. After reading the news, participants were presented with readers' comments to this news story, in an unedited version (they were just chronologically sorted). Material consisted of 20 comments (1504 words). Participants were instructed to highlight all sentences or phrases they found discriminatory towards Roma people.

At the end, participants were individually debriefed and thanked.

\section{Results}

Mood manipulation check. Subjects instructed to recollect a positive event reported to be in a more positive mood (Mhap=6.71; $(S D=1.32)$ ), in comparison to the ones instructed to recollect a negative event (Msad=3.09, $(S D=1.13))$. Difference between groups was statistically significant $(F(1,65)=140.7 ; p<.0001)$. Three subjects were excluded from further analysis for not complying with the mood induction procedure (they wrote about irrelevant events and/or did not focus on emotions they experienced).

Affective state and sensitivity to discrimination. All 66 participants followed the instructions and highlighted only meaningful phrases or sentences in the text. The number of highlighted words served as a dependent variable ${ }^{3}$. On average, they marked 145.5 words $(S D=12,47)$, approximately $10 \%$ of the text. More importantly, subjects in the sad mood (Msad=180.13 $(S D=18.15))$ marked significantly more words in comparison to happy subjects $($ Mhap $=114.82(S D=15.62))(F(1,68)=7.52 ; p<.0001)$.

\section{General discussion}

In the present research the influence of induced affect (happiness and sadness) on relying on stereotypes when making socially sensitive judgments was explored. Experiment one showed that, contrary to initial assumptions, happy and sad subjects did not differ in the number of stereotype consistent errors

3 I reasoned that, as there was no normative standard that could help us to classify "correct" and "incorrect" detection of discriminatory verbal behavior, using just the number of words can serve as an indicator of sensitivity to discrimination, regardless of the chosen content. Qualitative analysis of the content marked by respondents will be the topic of another paper. 
in memory task. In experiment two, however, happy subjects in comparison to sad subjects attributed more stereotypic traits to a non-stereotypical exemplar of a national category and expected him to behave more stereotypically in the future. Additionally, in thought listing task, happy subjects recorded more irrelevant and less story-focused thoughts in comparison to sad subjects. The third experiment demonstrated that subjects in sad mood tend to be more sensitive towards ethnic discrimination - they assessed more statements to be discriminatory in comparison to happy subjects. The differential impact on incidental affect on the use of stereotypes is usually explained by referring to people's capacity to process incoming information: namely, it is hypothesized that happiness decreases the amount of cognitive resources people invest in social judgment. This fact can be due to cognitive or to motivational decrement. The cognitive hypothesis argues that happiness decreases the total cognitive capacity (Mackie \& Worth, 1989; Worth \& Mackie, 1987). However, there are contradicting empirical findings showing that happy people are able to scrutinize the incoming information once they are explicitly instructed to do so (Bless et al., 1990; Schwarz, Bless \& Bohner, 1991; Schwartz \& Clore, 2007), or when made accountable for their judgments (Bodenhausen, Kramer, \& Susser, 1994). Therefore, it seems that motivation, rather then ability, causes different effects of sad and happy mood on reasoning. Two explanations may account for that: (a) hedonic approach argues that happy individuals allocate their resources to maintaining the pleasant state they are in, whilst sad individuals search for information in the environment that might improve their affective state (Wegener, Petty, \& Smith, 1995); (b) functionalist approach proposes that affective states serve as important information about the state of environment and that a negative state motivates the individual to change the situation; in order to accomplish that task, individual must have an accurate representation of the environment and therefore carefully processes incoming information (Schwartz, 2001; 2012). Findings of this study seem to support the general finding that happy mood is a mental state that predisposes reliance on heuristics and sad mood lowers such reliance. I obtained some evidence (the thought-listing task seems to be particularly persuasive) that sad people engage in more effortful elaboration of the incoming information, and that sad mood leads to more sensitivity to discriminatory behaviour towards an out-group. However, more research is warranted to investigate the mechanism behind it, and to prove robustness of the effect that emotional experience yields on social information-processing strategies.

\section{Acknowledgments}

This research was funded by the grant from the Ministry of Education and Science of the Republic of Serbia (project number 179018). The author wants to thank Milka Subotić, Marijana Tadić, Maša Vukčević, Jovana Dačković and Dubravka Radusinović for collecting and analyzing portions of the data. 


\section{References:}

Bless, H., Bohner, G., Schwarz, N., \& Strack, F. (1990). Mood and persuasion: A cognitive response analysis. Personality and Social Psychology Bulletin, 16, 331-345.

Bless, H., Schwarz N., Bodenhausen G. V. \& Thiel, L. (2001). Personalized versus generalized benefits of stereotype disconfirmation: Trade-offs in the evaluation of atypical exemplars and their social groups. Journal of Experimental Social Psychology 37, 386-397.

Bless, H., Schwarz, N., \& Wieland, R. (1996). Mood and the impact of category membership and individuating information. European Journal of Social Psychology, 26, 935-959.

Bodenhausen, G. V. (1993). Emotion, arousal, and stereotypic judgments: A heuristic model of affect and stereotyping. In D. M. Mackie \& D. L. Hamilton (Eds.), Affect, cognition, and stereotyping: Interactive processes in group perception (pp. 13-37). San Diego, CA: Academic Press.

Bodenhausen, G. V., Gabriel, S., \& Lineberger, M. (2000). Sadness and susceptibility to judgmental bias: The case of anchoring. Psychological Science, 11, 320-323.

Bodenhausen, G. V., Kramer, G. P., \& Süsser, K. (1994). Happiness and stereotypic thinking in social judgment. Journal of Personality and Social Psychology, 66, 621632.

Bodenhausen, G. V., Mussweiler, T., Gabriel, S., \& Moreno, K. N. (2001). Affective influences on stereotyping and intergroup relations. In J. P. Forgas (Ed.), Handbook of affect and social cognition (pp. 319-343). Mahwah, NJ: Erlbaum.

Bodenhausen, G. V., Sheppard, L., \& Kramer, G. P. (1994). Negative affect and social perception: The differential impact of anger and sadness. European Journal of Social Psychology, 24, 45-62.

Forgas, J. P. (1998). On being happy and mistaken: Mood effects on the fundamental attribution error. Journal of Personality and Social Psychology, 75, 318-331.

Forgas, J. P. (2007). When sad is better than happy: Negative affect can improve the quality and effectiveness of persuasive messages and social influence strategies. Journal of Experimental Social Psychology, 43, 513-528.

Forgas, J. P., Vargas, P., \& Laham, S. (2005). Mood effects on eyewitness memory:

Affective influences on susceptibility to misinformation. Journal of Experimental

Social Psychology, 41, 574-588.

Kluegel, J. R., \& Bobo, L. (2001). Perceived Group Discrimination and Policy Attitudes: The Sources and Consequences of the Race and Gender Gaps. In O’Connor, A., Tilly, C., \& Bobo, L. (Eds.), Urban inequality: Evidence from four cities (pp. 162-213). New York: Sage.

Lerner J.S., \& Tiedens L.Z. (2006). Portrait of the angry decision maker: how appraisal tendencies shape anger's influence on cognition. Journal of Behavioral Decision Making, 19, 115-137.

Mackie, D.M. \& Hamilton, D.L. (1993). Affect, cognition and stereotyping. Interactive processes in group perception. San Diego, CA, Academic Press. 
Mackie, D. M., \& Worth, L. T. (1989). Cognitive deficits and the mediation of positive affect in persuasion. Journal of Personality and Social Psychology, 57, 27-40.

Schwarz, N. (2001). Feelings as information: Implications for affective influences on information processing. In L. L. Martin \& G. L. Clore (Eds.), Theories of mood and cognition: A user's handbook (pp. 159-176). Mahwah, NJ: Erlbaum.

Schwarz, N. (2012). Feelings-as-information theory. In P. Van Lange, A. Kruglanski, \& E. T. Higgins (Eds.), Handbook of theories of social psychology (pp. 289-308). New York: Sage.

Schwarz, N., Bless, H., \& Bohner, G. (1991). Mood and persuasion: Affective states influence the processing of persuasive communications. In M. Zanna (Ed.), Advances in experimental social psychology (Vol. 24, pp. 161-197). New York: Academic Press.

Schwarz, N., \& Clore, G. L. (2007). Feelings and phenomenal experiences. In E. T. Higgins \& A. W. Kruglanski (Eds.), Social psychology: Handbook of basic principles (2nd ed., pp. 385-407). New York,: Guilford.

Strack, F., Schwarz, N., \& Gschneidinger, E. (1985). Happiness and reminiscing: The role of time-perspective, mood, and mode of thinking. Journal of Personality and Social Psychology, 49, $1460-1469$.

Park, J. \& Banaji M. R. (2000). Mood and heuristics: The influence of happy and sad states on sensitivity and bias in stereotyping. Journal of Personality and Social Psychology, 78, 1005-1023.

Popadić D., Biro, M. (2002): Autostereotipi i heterostereotipi Srba u Srbiji [Autostereotypes and heterostereotypes of Serbs in Serbia]. Nova srpska politička misao, posebno izdanje 3, 33-55.

Ric, F. (2004). Effects of the activation of affective information on stereotyping: When sadness increases stereotype use. Personality and Social Psychology Bulletin, 30, $1310-1321$.

Storbeck J., \& Clore G. L. (2005). With sadness comes accuracy; with happiness, false memory: Mood and the false memory effect. Psychological Science, 16, 785-791.

Wegener, D. T., Petty, R. E., \& Smith, S. M. (1995). Positive mood can increase or decrease message scrutiny: The hedonic contingency view of mood and message processing. Journal of Personality and Social Psychology, 69, 5-15.

Worth, L. T., \& Mackie, D. M. (1987). Cognitive mediation of positive mood in persuasion. Social Cognition, 5, 76-94. 


\title{
Uticaj eksperimentalno izazvanih afektivnih stanja sreće i tuge na etničko stereotipiziranje
}

\author{
Iris Žeželj \\ Odeljenje za psihologiju, Filozofski fakultet, Univerzitet u Beogradu
}

Incidentalna afektivna stanja utiču na stereotipiziranje na relativno neočekivan način: eksperimentalno izazvano osećanje sreće vodi ka većem oslanjanju na stereotipe pri zaključivanju, dok eksperimentalno izazvano osećanje tuge vodi ka manjem oslanjanju na stereotipe. U istraživanju smo pošli od sledećih pretpostavki: a) srećni ispitanici u poređenju s tužnim ispitanicima praviće više stereotipno-kongruentnih grešaka u zadatku pamćenja; b) srećni ispitanici u poređenju s tužnim ispitanicima pripisaće više stereotipnih osobina pripadnicima određene etničke grupe i c) srećni ispitanici u odnosu na tužne ispitanike biće manje osetljivi na etničku diskriminaciju. U prva dva eksperimenta učestvovalo je 90 punoletnih učenika iz dve beogradske srednje škole. Kod ispitanika je u prvoj fazi oba eksperimenta izazvano odgovarajuće raspoloženje (sreća ili tuga) pomoću procedure prisećanja događaja iz sopstvenog života. U prvom eksperimentu ispitanicima je prezentovana lista nacionalno tipičnih imena (za Srbe i Albance), s pridruženim zanimanjima koja su prethodno procenjena kao tipična za jednu i drugu grupu. Nakon toga ispitanici su imali zadatak da navedenom imenu pridruže određeno zanimanje. Stereotipno kongruentnom greškom smatrala se situacija u kojoj ispitanici imenu (pogrešno) pridružuju nacionalno-tipično zanimanje (npr. uz albansko ime navedu zanimanje pekar). Ispitanici su uglavnom grešili na stereotipno-kongruentan način, ali se srećni i tužni ispitanici nisu značajno razlikovali u proporciji takvih grešaka. U drugom eksperimentu ispitanicima je prezentovana vinjeta u kojoj je opisan umereno atipičan mladi Albanac, a zatim se od njih tražilo da mu pripišu niz osobina i pretpostave verovatnoću o dogadjajima u koje će se u budućnosti upustiti. Srećni subjekti su mu pripisivali značajno više stereotipnih osobina i očekivali su da će se on stereotipnije ponašati u budućnosti. Pored toga, u zadatku "liste misli" srećni subjekti su naveli veći broj irelevantnih misli,. U trećem eksperimentu učestvovalo je 66 studenata psihologije. Na isti način kao u prva dva ogleda o u njima je izazvano srećno, odnosno tužno raspoloženje. Nakon toga prezentovana im je internet-vest s komentarima čitalaca i od njih je traženo da označe tvrdnje u komentarima koje su, po njihovom mišljenju, diskriminišuće prema konkretnoj etničkoj grupi (Romima, u ovom slučaju) Tužni ispitanici su u poređenju sa srećnim ispitanicima ispoljili veću osetljivost na diskriminaciju. Nalazi su diskutovani u kontekstu uticaja afektivnog stanja na strategije obrade socijalno-relevantnih informacija.

Ključne reči: afektivno stanje, tuga, sreća, stereotipi, osetljivost na diskriminaciju. 